participated in the successful brainwashing of the profession, so that the phrase "a judge can direct a doctor to give evidence" (Dr. J. W. MacLeod, 8 May, p. 339) will probably go entirely unchallenged except in this letter. A judge can, indeed, direct a doctor to give evidence, but the guidance from the General Medical Council on this matter should be that a doctor may give the evidence, or refuse and risk prison for contempt, according to his conscience, and that the profession and the General Medical Council will stand behind such a doctor.

I suppose I am being unfair, but my feeling is that the critics of Dr. Browne must include some who have, instead of participating in the resolution of ethical problems that arise from our changing times, used the General Medical Council and the British Medical Association's Ethical Committees as a safe deposit for their consciences.

I am sure that my views on sexual behaviour in the permissive society are as different from Dr. R. J. D. Browne's as they could possibly be. I am also sure that as a patient I would be better served by his conscience than by any court, committee, or council.-I am, etc.,

Charles I. Finn

Leavesden Hospital

Abbots

SIR, -I am interested in the views expressed in your journal by various correspondents on the issue of confidentiality which has arisen since the Dr. R. D. J. Browne case. I am not a doctor-merely the wife of onebut I am a parent, and I wonder if the people who think Dr. Browne was wrong have any daughters of their own.

We have three daughters and we would be extremely angry if any clinic doctor prescribed anything for them without consulting us. I think that most parents who care for their children feel the same. Those who don't care won't mind knowing, so I can't see the sense of this secrecy.

How do these clinics know whether a girl is over 16 or not, and do they know or care about the medical history of her family or the religious objections the family may have to their policies? Presumably people are still allowed in this democracy to have moral and religious beliefs.

I hope that parents are not going to be regarded as meal tickets and providers of clothes and lodgings only.-I am, etc.,

Lancing,

NANCY KING Sussex

\section{Life Jackets}

SIR,-I would like to write and point out to colleagues that I feel very strongly that life jackets (life savers in the U.S.A. and Canada) should be worn on all sailing or small craft pursuits at all times. However strong a swimmer the sailor in small craft is very vulnerable and, if thrown into the water, at least he has a chance of survival during the warmer months. Only this last weekend, a young man died when his small fibre-glass craft turned over in Rye Bay. His companion was more fortunate and recovered with professional care.

Surely legislation would not only save the lives of those whose recreation is in small craft but also potentially those of other people going to their rescue-usually the fast inshore lifeboats currently being used from many harbours.

Seventeen men from the village of Rye Harbour lost their lives in 1928, when they answered a false call to a larger vessel in distress. This is particularly poignant when the necessary legislation could so easily be passed through Parliament. Indeed, in many cases, those who go down to the sea in ships today are very poor sailors, and it is surely time that sornething is done.-I am, etc.,

Rye Harbour,

PHILIP DOusT

\section{Hospital Staff Appointments}

SIR,-For some time there have been occasions in the Pontypridd and Rhondda Hospital Management Committee area (and in others, judging by personal communications) on which candidates for hospital stafi appointments have been offered, and accepted, the said appointments, but have subsequently accepted a later offer of employment elsewhere. Apart from the sheer dishonesty and lack of integrity displayed thereby (save where overwhelming personal reasons may have been invoked) the resulting administrative chaos has to be experienced in order to be realized.

It would seem the only practical way in which to forestall this unpleasant situation in the future would be by the inauguration of a central register of available candidates for hospital appointments. An intending candidate would inform the register of his availability, whereupon his name would be placed on a list and retained thereon until he had accepted an appointment. Immediately on that event his name would be withdrawn from the "available" list, on receipt of (telephoned) notification from the employing authority; and he would be unable to return to the register's list until "cleared" by his employer at the end of his term of office or other agreed condition. The expense and administrative requirements of such a register would be far less than those at present result ing from candidates' behaviour discussed above. It is time this scandalous practice was stopped.--I am, etc.,

East Glamorgan Hospital,

J. DE SWIET Pontypridd, Glam

\section{Review of the Abortion Act}

SIR,-It surely casts great doubt on the value of the B.MA. Abortion Law investigation when the chairman of the committee holds strong beliefs on the subject (Supplement, 8 May, p. 88). No matter how valuable the findings of the committee may be, in fact they will be questioned by the public at large on these grounds alone.-I am, etc.,

Claybury Hospital,

A. O. Diver

Claybury Hospital,
Woodfordbridge, Essex

\section{B.M.A. Board of Science Reports}

SIR,-Having seen two sets of headlines in my daily paper (The Times, 7 May) referring to B.M.A. Board of Science reports, I feel I must protest.
Firstly, referring to the aged, handicapped, etc., patients, it blames everybody but ourselves. Yet doctors carry the major share of the blame; as general practitioners for inadequate care, particularly of the aged; and general practitioners and specialists for not pressing for better facilities where these are necessary. The National Health Service is an excellent scheme, but is as good as the people who run it. The faults are ours for opting out of running the scheme.

Secondly, referring to abortion, suggesting a lowering of the age of consent for intercourse. In this permissive and promiscuous society we, as responsible and privileged members of the community, should be setting an example, not condoning and encouraging these trends. If lowering the age is proposed merely because intercourse takes place, then surely the age for smoking and drinking should be lowered.

These reports should not be published acknowledging the B.M.A. and thereby inferring its approval, until they have been accepted by the Annual Meeting or at least the Council.-I am, etc.,

G.M.INGALL

Congtown,

\section{G.M.C. and Registration Delays}

SIR,-Dr. G. Cameron (8 May, p. 342) and Dr. D. S. Wright (15 May, p. 406) complain of delay in registering their additional qualifications. The delay arises from the interplay of two factors.

All alterations in the Register now have to be processed through machines called Flexowriters in order to reach the computer tape. Since these machines are costly, only sufficient have been purchased to deal with the level of transactions which is expected to continue in future years. At present the number of alterations requiring action is abnormally high.

The introduction of annual retention fees stimulated in 197020,000 applications for transfer to the Overseas List, and 35,000 requests for changes of address. Over 8,000 requests for registration of additional qualifications were also received. Before 1970 there was no Overseas List. Each year about 10,000 requests for a change of address were received and 1,000 for the registration of additional qualifications.

In a situation where it is impossible to process immediately all requests for alterations in the Register, priority must be given to new registrations (over 7,500 each year). Nevertheless, well over 3,000 additional qualifications have been registered during the past year, and outstanding applications are being dealt with as quickly as circumstances permit.-I am, etc.,

M. R. DRAPER General Medical Council London W.1

\section{Resuscitation of Drowned Children}

SIR,-The presently recommended first aid after drowning, as described for me by Surgeon Rear-Admiral Stanley Miles, is "a rapid swabbing or tipping out of any obvious fluid or debris in the mouth and immediate exhaled air resuscitation." He 
advocates gentle handling and the adoption of the semiprone position during the recovery period to prevent inhalation if the patient should vomit.

During a hospital round some years ago I found a child about 4-years-old lying in his cot black in the face and almost dead, obviously from inhaled vomit. Instinctively I picked him up by his thighs, put them over my head, got the house surgeon to hold his feet behind me, and respired him in the head down position. Vomit and mucus poured from his mouth and he recovered consciousness immediatcly.

It seems common sense to apply this method initially to drowned children. The smaller the child the easier it is. From infancy to a child about $4 \mathrm{ft}$. $(125 \mathrm{~cm})$ in height, one rescuer is sufficient-the first step being to tie the ankles or knees together quickly with anything handy; or the child's own bathing trunks or shorts may be drawn down to the knees. The rescuer then thrusts his head between the child's thighs, stands up, and starts artificial respiration. Though two rescuers are ideal even for a child under $4 \mathrm{ft}$. tall, they are probably mandatory for one above this height.

The photographs show the three stages of the method with two rescuers. The boy (an old patient of mine who entered into the spirit of the thing) was aged 9 and $4 \mathrm{ft} .5 \mathrm{in}$. (137 cm) in height. I chose him as a model because he seemed to be of about the maximum height in which the method could be useful even with two rescuers, but at a pinch I could have managed him by muself.

The possible advantages of the method are that water drains from the mouth (? also from the stomach) with each compression of the chest by the rescuer's hands. There is no question of the tongue falling back or of re-inhalation of fluid; external cardiac massage could be applied (by trained staff) by thumping with the right hand at intervals; and the rescuer(s) could walk some distance for help while maintaining respiration.

Possible criticisms of the method are whether the lungs would expand after each compression, especially with the weight of the abdominal contents. My doubts are, I think, resolved by the probability that the weight of the dependent arms and pectoral girdle would expand the rib cage passively, as in the Silvester method. Tidal volume might be less than in the mouth-to-mouth method, but this seems less urgently important than immediate evacuation of any water in the larger bronchi. I asked Professor Keith Simpson's advice on this and he agreed that the initial use of gravity would seem to be an dvaantage.

Cerebral venous congestion could be expected, but would probably do nothing but good over a short period, especially in the absence of a heart beat. The method would be irrelevant in the minority cases of "dry" drowning. If no fluid escaped from the mouth in the head down position, exhaled air respiration would be started immediately.

My own impression is that any benefit from using this method would be achieved within one or at most two minutes-the time taken for all unfixed water to be drained from the lungs. At the moment then, the suggested plan involves artificial respiration head down for a limited period, followed by mouth-to-mouth respiration when the lungs are relatively clear.

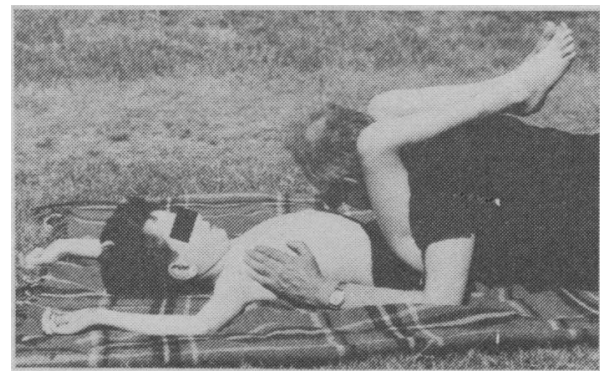

Stage 1

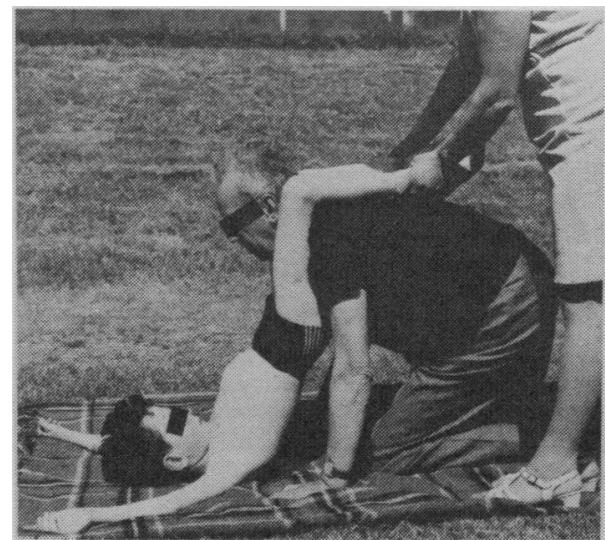

Stage 2

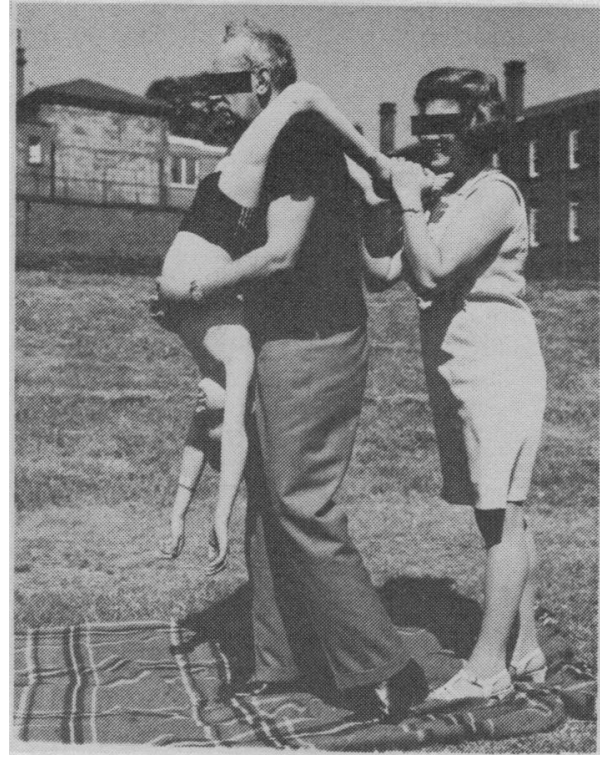

Stage 3. The rescuer's hands are too high-a mistake casily made.

My thanks are due to Professor Keith Simpson for his advice and encouragement; to Rear Admiral Stanley Miles, consultant in physiology to the vice-chairman of the Medical Commission on Accident Prevention for his helpful criticism, and to my model and his mother for their cooperation.

-I am, etc., Brook General Hospital,
London S.E.18

J. R. GibBS

\section{Lymphocyte Sensitization in Sarcoidosis}

SIR,-The paradox of skin hyporeactivity yet efficient antibody production in sarcoidosis is almost resolved by the interesting findings of Dr. E. A. Caspary and Professor E. J. Field (17 April, p. 143). The cases showed lymphocyte sensitization to purified protein deriva- tive in their blood, despite the fact that most of them had negative Mantoux tests. Three patients probably had positive Mantoux reactions, but none had delayed hypersensitivity to tuberculosis on Kveim testing. (We also noted this, in retrospect, in a case which was Mantoux and Kveim positive. ${ }^{1}$ ) The sensitized lymphocytes thus reacted directly with the antigens, but "the chain of events leading indirectly to nonspecific skin inflammation"2 was broken. The immune response itself may have altered the primary pathogenic agent out of all recognition. The sarcoid agent is perhaps a dead or phage-infected organism, ${ }^{3}$ likely to react differently from a live one. Sarcoidosis arises in patients with brisk immune responses and there is often a family history of tuberculosis. Freund's adjuvant inoculated into animals injures the affected tissues and granulomas may appear. The common denominator may be suitably processed mycobacteria.

The lymphocyte sensitization test will be most valuable if it is simplified. Once recovery is under way, sarcoidosis is not often diagnosable. Many chronic illnesses must remain only syndromes when early chenges are unnoticed. It is more important to retrieve undiagnosed and serious cases than to confirm "recovered" or "latent" sarcoids. -I am, etc.,

G A. MACGREGO

Chilworth, Surrey

1 Leppard, B. I., and MacGregor, G. A., Proceedings of the Royal Society of Medicine, 1971, G4

2 Turk, J. L., Immunology in Clinical Medicine, p. 43. London, Heinemann, 1969.

International Conference on Sarcoidosis. Fourth Masson, 1967.

\section{Hypercapnia}

SIR,- "Hypercapnoea" has been seen again puffing with vigour (23 January, p. 220). It really is about time that it expired, for, used in a context as identical with "hypercapnia," the earlier word proves that it should not exist. "Hypercapnia" does make sense from its Greek derivation: $\psi \pi \epsilon \rho$ above, beyond кanvos smoke: hence $\mathrm{CO}_{2}$. The ideas behind the suggested alternative are confusing. Someone, somewhere, clearly got confused by the quite acceptable use of the root from

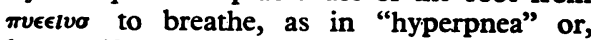
longer if not purer, "hyperpnoea."

So "hypercapnoea" is nasty. I therefore write in the defence of "hypercapnia," with the possibly vain hope that I might stop one more step in that contagion of catachresis, coining ever worse words rather than making use of those already around.-I am, etc.

ROGER J. LEWIS

Department of Infectious Diseases,

Cook County Hospital,

\section{Points from Letters}

Masturbation and Guilt

Dr. A. J. BYron (Sheffield, Yorks) writes: As any psychiatrist worth his salt knows anxiety over masturbation figures prominently in the morbid thinking of many patients with severe neuroses and depressive illnesses. The recent massive publicity given to this topic in the media of mass communication can hardly fail to have captured the attention of the vast proportion of the public. The effect of this must 'srirely be to effect a natural desensitization of guilt and anxiety over adolescent masturbation. . 